\title{
Management of severe attacks of ulcerative colitis with new technologies
}

\author{
M CAMPIERI, P GIONCHETTI, A BelluZZI, M TAMPIERI, C BrigNOLA, E BERTINELli, \\ V ARIENTI, P IANNONE, M MIGLIOLI, L BARBARA
}

\begin{abstract}
Barium enema and colonoscopy are contraindicated in severe attacks of ulcerative colitis because of the possibility of toxic megacolon and perforation. The authors have assessed abdominal ultrasound in 38 patients with severe ulcerative colitis. Ultrasound revealed bowel wall thicknesses ranging from 3.9 to $9.2 \mathrm{~mm}$ (mean 7.7) extending the whole length of the colon, to the transverse colon, and to the descending colon, respectively, in 18, 10 and eight patients. The degree of bowel thickening was related to the severity of inflammation based on clinical, sigmoidoscopic and histological evaluation. In two patients, ultrasound showed a thin bowel wall distended without motility, suggesting the diagnosis of toxic megacolon (confirmed radiologically). An excellent correlation (95\%) was found between ultrasound and technetium-99 scanning. Ultrasound might be a reasonable first investigation in the assessment of patients with severe ulcerative colitis. Can J Gastroenterol 1990;4(7):347349
\end{abstract}

Key Words: Diagnosis, Nuclear scanning, Ulcerative colitis, Ultrasound

\section{Nouvelles technologies et traitement des poussées graves de colite ulcéreuse}

RESUME: A cause d'un mégacôlon toxique et d'une perforation possibles, le lavement baryté et la côlonoscopie sont contre-indiqués dans les poussées graves de colite ulcéreuse. Les auteurs évaluent le recours à l'échographie abdominale chez 38 patients porteurs de colite ulcéreuse sévère. Cette démarche a révélé que la paroi de l'intestin mesurait de 3,9 à 9,2 $\mathrm{mm}$ (épaisseur moyenne de 7,7 mm) sur toute la longueur du côlon, le côlon transverse et le côlon descendant, respectivement, chez 18, 10 et huit patients. Le degré d'épaississement du côlon était fonction de la gravité de l'inflammation évaluée selon des modalités cliniques, sigmoïdoscopiques et histologiques. Chez deux patients, l'échographie a révélé une paroi mince, distendue et sans motilité, suggérant un mégacôlon toxique que la radiographie a confirmé. Il existe une excellente corrélation (95\%) entre l'échographie et la scintigraphie au technétium 99. L'échographie constituerait donc un premier mode d'investigation raisonnable dans l'évaluation des patients souffrant de colite ulcéreuse sévère.

Istituto di Clinica Medica e Gastroenterologia, Universita di Bologna, Bologna, Italy Correspondence and reprints: Dr M Campieri, Istituto di Clinica Medica e Gastroenterologia, Universita di Bologna, Bologna, Italy
Cevere attacks of ulcerative colitis represent an extremely dangerous condition for patients and require prompt and careful management. In the old days (ie, previous to the corticosteroid era) severe ulcerative colitis was associated with a high fatality rate, but now, thanks to clear guidelines, the mortality has fallen to zero.

An attack is defined as severe when a patient presents with more than six bowel movements per day, fever, tachycardia, increase of erythrocyte sedimentation rate greater than 30 and decrease in hemoglobin of at least onethird (1). A moderately severe attack occurs with more than five to six bowel movements daily without evidence of systemic disease. An intensive intravenous regimen, ie, high dose corticosteroids (prednisolone $60 \mathrm{mg}$ daily), induces remission in about $70 \%$ of patients. This treatment, combined with immediate surgery in the patient who does not respond to medical treatment, has greatly modified the prognosis (2). From current knowledge of the natural history of ulcerative colitis, it is well known that the outcome of an attack of ulcerative colitis is closely dependent on the severity of the inflammatory process, extent of disease and response to medical treatment (3). Therefore, it is important to measure such parameters in severe cases. 
When the disease shows such severity, the patient cannot be managed using traditional techniques, such as colonoscopy or double contrast barium enema because of the risk of worsening the course of the disease or precipitating toxic megacolon. Therefore, the assessment of these patients has so far been based mainly on the observations of changes in clinical parameters, eg, the number of bowel movements and bloody stools, and on the monitoring of plasma parameters. Examining the distal portion of the colon with distal sigmoidoscopy may be helpful, but the results of this latter examination can be masked by concomitant topical treatment.

\section{ULTRASONOGRAPHY AND SCANNING WITH LABELLED LEUKOCYTES}

In recent years, fortunately, new diagnostic techniques have been introduced in the management of patients with inflammatory bowel disease (IBD).

The first is scintigraphy, which consists of the intravenous administration of autologous leukocytes labelled with radioisotopes. The technique of scanning with autologous leukocytes is based on the very simple principle that leukocytes migrate towards an inflammatory process. Therefore, when these cells are labelled with a radionuclide such as indium-111 or technetium-99, is possible to map the area of inflammation, not only in terms of localization, but also in terms of intensity (4-5). The more recently introduced technique of labelling leukocytes with technetium99 offers a substance which possesses the same labelling capacity but a shorter half-life than indium-111 (5).

As well, abdominal ultrasonography has been shown to be useful in the management of patients with IBD. This technique has been of value for detecting bowel thickening due to an inflammatory process. It has been used satisfactorily in patients with Crohn's disease because it can show modifications of the intestinal wall such as stricture, and is also of value in detecting abdominal abscesses (6).

So far in patients with ulcerative colitis its use has been rather limited. In the authors' routine clinical experience they noticed that in patients with mild active ulcerative colitis, abdominal ultrasonography was not able to detect any significant change. However, when a patient complains of a severe attack it is possible to observe a generalized thickening of the intestinal wall.

Therefore, from these preliminary experiences it seems that abdominal ultrasound examination may be useful for assessing extent of disease, severity of inflammation and response to medical treatment.

\section{THE AUTHORS' EXPERIENCE}

The authors have followed 24 patients with severe attacks of ulcerative colitis, according to the clinical definition, and an additional 18 who were admitted to hospital because of moderately severe attacks. All patients were managed with an intensive intravenous regimen for 10 days and assessed clinically and sigmoidoscopically, at the beginning and end of treatment. According to the above parameters it was judged whether a patient should undergo surgery or continue with medical treatment.

The first day each patient was assessed with an abdominal ultrasound which revealed thickening of the bowel wall and the extent of inflammation. The examination consisted of an abdominal ultrasound examination using a Siemens machine with a $5 \mathrm{MHz}$ detector. During the examination the whole colon was examined, when possible. The extent of inflammation was registered and the thickness of the colonic wall measured with calipers. At the end of each examination it was also possible to obtain a value for disease activity by measuring thickness and multiplying by the number of involved segments in each of the four regions considered (rectosigmoid, left, transverse and right colon).

On the second day, in two-thirds of patients, a scintigraphic examination using leukocytes labelled with technetium-99 was performed. Using this technique the extent of disease was revealed and an activity score obtained according to Saverymuttu et al (4).
This score is obtained in each of the four regions, ie, rectosigmoid, left, transverse and ascending colon.

In this preliminary approach the authors tried to find a correlation be. tween the scintigraphic activity score and the ultrasonographic score. This correlation was highly statistically sigr nificant $(\mathrm{P}<0.001)$. The ultrasound score showed good correlation with the clinical activity symptoms. After 10 days the ultrasound examination was repeated and the data analyzed a before.

From a practical point of view, when the thickness of the colonic wall was computed before and after treatmentin patients who did respond to medical treatment, a marked decrease (about30 to $40 \%$ ) was observed. Apparenty when the same observation was carried out in patients who did not respond to medical treatment, practically no change was observed in colonic wall thickness.

A comparison of the data regarding extent of disease obtained by ultrar sound, scintigraphy and operatory specimens was carried out. It appears that scintigraphy is slightly more sensi. tive than ultrasound in detecting inflammation in the right colon However, ultrasound was able to distinguish between inflammation localized to the left or transverse colon. Ultra sound examination was also extremely useful in detecting toxic megacolon.

From the preliminary data presented here it seems possible to imagine a role for ultrasound in assessing severity of disease and extent of inflammation, but mainly in following patients before and after treatment. From the authors' experience, it seems that ultrasound may provide an objective diagnostic tool.

Another important factor is the analysis of cost/risk benefit. Scintigraphy cannot be repeated, at least not in the short term, because of risks related to radioactivity. In Italy the cost of a scanning examination is abour US $\$ 250$ and the time necessary to perform the test, considering the time for obtaining cells, is about 3 to $5 \mathrm{~h}$. Ultrasound abdominal examination, however, can be repeated whenever convenient, and is simple to perform 
Costs are relatively low, at US\$50 for each examination, and the time required is about 5 to $10 \mathrm{mins}$.

\section{CONCLUSIONS}

From the above considerations it appears that both scintigraphy and ultrasound are extremely useful techniques in patients with severe ulcerative colitis. In particular, ultrasound offers many advantages for the management of this condition. Therefore, in addition to the traditional techniques, the authors suggest ultrasonography as routine approach for these patients.

\section{REFERENCES}

1. Truelove SC, Richard WCD. Biopsy studies in ulcerative colitis. Br Med J 1956;1:1315-8.

2. Truelove SC, Jewell DP. Intensive intravenous regimen for severe attacks of ulcerative colitis. Lancet 1974;i:1067.

3. Edwards FC, Truelove SC. The course and prognosis of ulcerative colitis. Gut 1963:4:220-315.

4. Saverymuttu SH, Camilleri M, Rees H, et al. 111-Indium granulocyte scanning. Comparison with colonoscopy, histology, and fecal 111 -indium excretion in assessing disease extent and activity in colitis. Gastroenterology 1968;90:1121-8,

5. Peters AM, Danpure HJ, Osman S, et al. Clinical experience with $99 \mathrm{mTc}$ hexamethylpropylene-amineoxime for labelling leucocyte and imaging inflammation. Lancet 1986;ii:946.

6. Worliccek H, Lutz H, Thoma B. Sonography of chronic inflammatory bowel disease. A prospective study. Ultraschall Med 1986;7:275-80. 


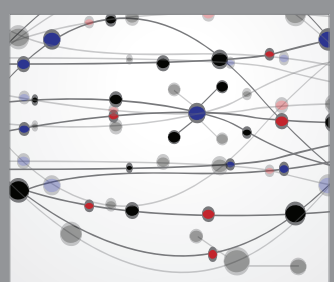

The Scientific World Journal
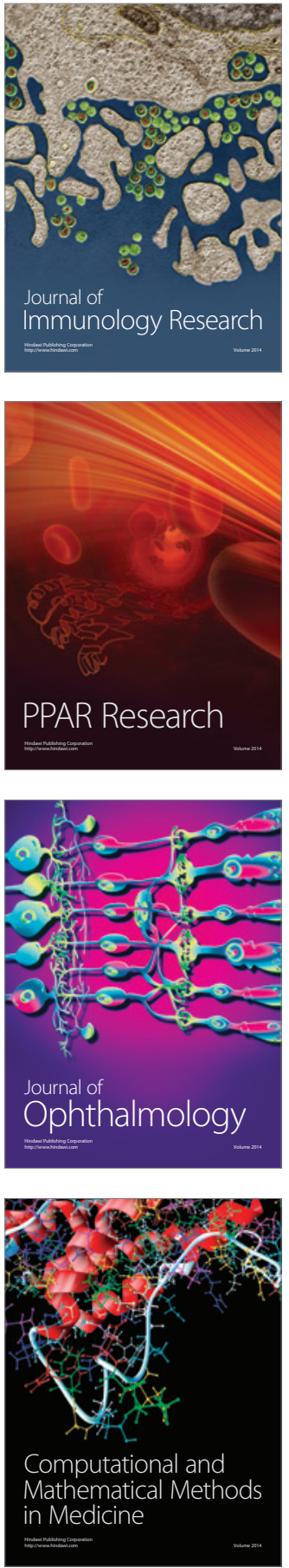

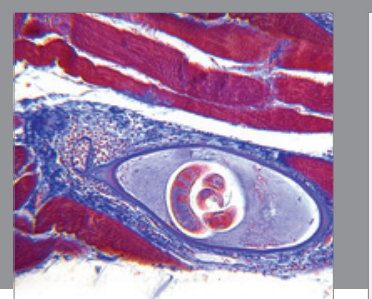

Gastroenterology Research and Practice

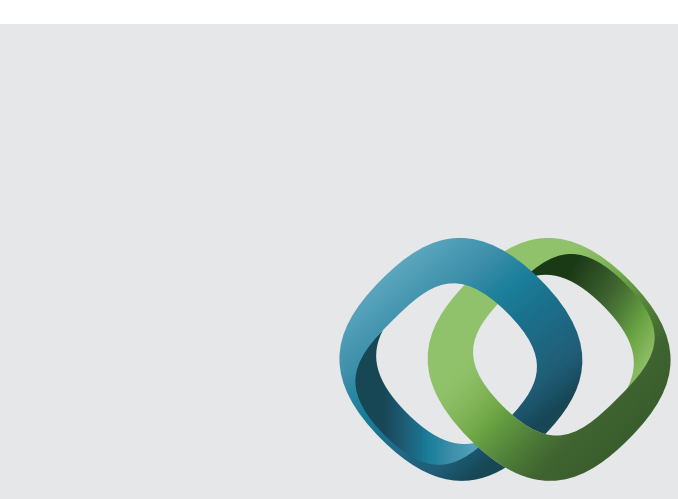

\section{Hindawi}

Submit your manuscripts at

http://www.hindawi.com
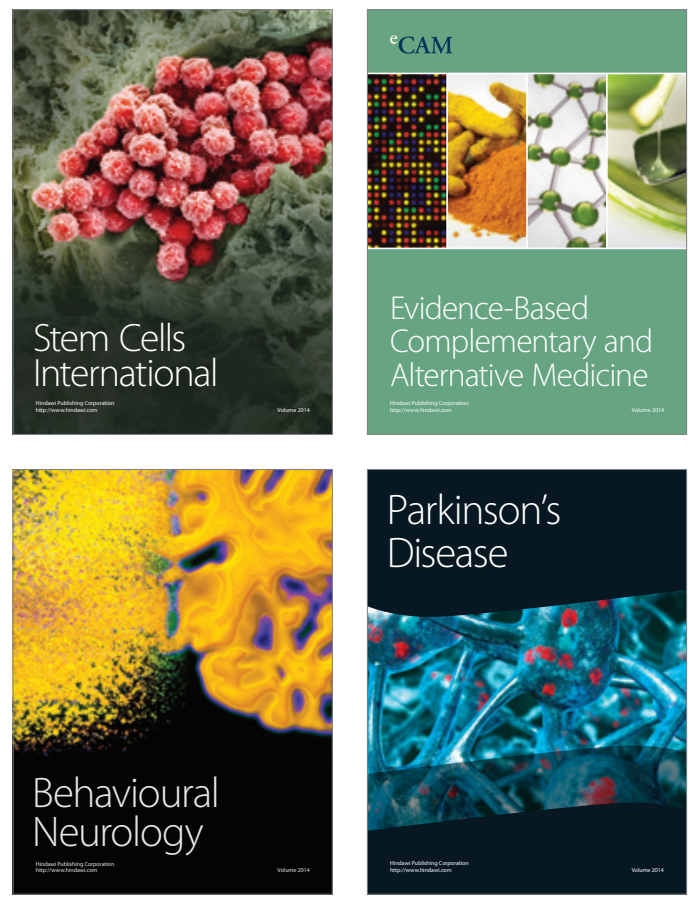
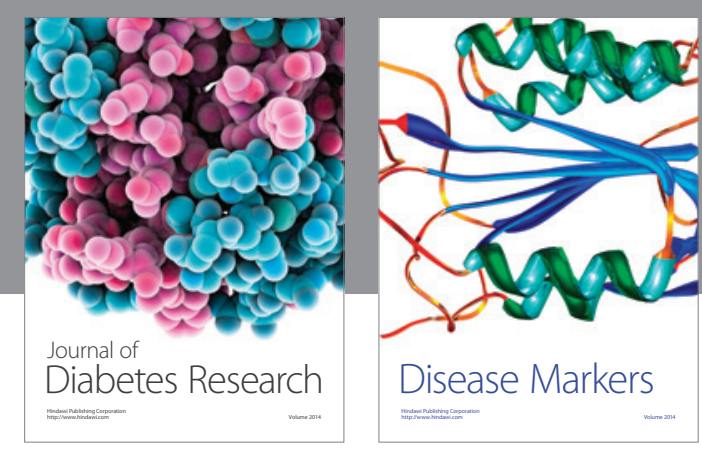

Disease Markers
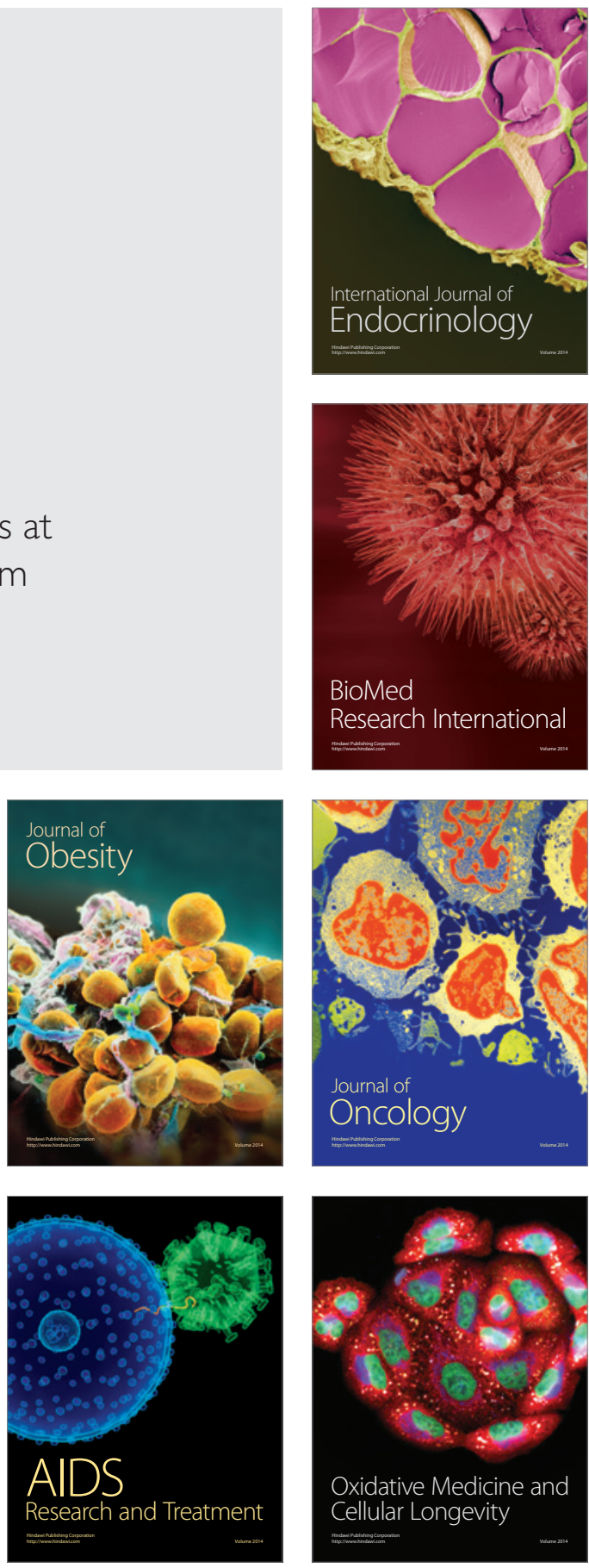